\title{
Science For Social Welfare and Justice
}

\author{
Shukri Ahmad \\ School of language, Civilization and Philosophy \\ Universiti Utara Malaysia \\ Sintok, Malaysia \\ shuk494@uum.edu.my
}

\author{
Musa Yusuf Owoyemi \\ School of language, Civilization and Philosophy \\ Universiti Utara Malaysia \\ Sintok, Malaysia
}

\begin{abstract}
Science has made many positive contributions and, at times, negative ones to the world's population. The discovery of scientists enables humans to produce new civilizations that are drastically different from the previous ones. At the contemporary time, the key actor of this difference in civilization is the internet. The Internet has narrowed distances, shorten time and create a universe that seems like a small village. This phenomenon has created a situation in which questions about the relationship between science, social justice and social well-being has come to the fore and is, thus, the focal point of this article. This paper discusses the relationship between science, social justice and social well-being. It posits that social justice has a very close relationship with the rule of religion, the state and power. Religion actually advocates justice. However, religion is also often used by various parties, including those who are in power to legalize misbehavior and injustice towards subordinates and others who are different from them. The paper posits that some dimensions of social justice, such as dignity, equality, brotherhood, well-being, freedom and welfare could help position science for the good of humanity. In conclusion, the paper posits that science and technology when properly harnessed following the outlined dimension could be a tool for social justice and welfare
\end{abstract}

Keywords - Science; social justice; social media and Islam

\section{INTRODUCTION}

The burst of science in this century was like a wild dragon. New discoveries related to science and technology appear everywhere in the world. Since the discovery of satellite technology, all natural resources have been exploited in the name of scientific studies. The world now seems to be very small. Scholars referred to this new phenomenon as globalization - or a global village's era. [1]. Everyone is in the same village, where the people can use the same technology that is capable of getting the information very quickly from one end of the world to another and where people all over the world function as if they live in the same village. In short, this is the era of the discovery of science and technology and what they are capable of achieving for human beings. Today, there are dozens of search engines which provide a variety of information at the click of a mouse. All information from the internet sources can be used by anyone to get close to varieties of knowledge and information on any issue or topic of choice. However, there are times when the information can bring a lot of benefits to the person and there are times that such information could be harmful to the person, his fellow humans as well as to the world in general. Likewise, because of the heavy raft of data that is available on the internet, a person may mistakenly come into contact with or collect information that could potentially lead to a lot of vices and problems relating to moral, natural, and environmental disasters. Thus, thus, signals the disaster that could accrue to human beings as a consequence of the breakthrough of science and technology. Obviously, science seems to be like a sharp knife that can do a lot of good, but can also constitute a harmful and dangerous tool for mankind.

\section{WHAT DOES SCIENCE REALLY MEAN?}

Science is a term derived from the Latin word "Scientia" which stands for knowledge. It refers also to the determination of scientific, wisdom or ability to separate something from something else. It also said to be "the intellectual and practical activity encompassing the systematic study of the structure and behavior of the physical and natural world through observation and experiment." Scientific research covered studies of plants, animals, earth, sky, wind and weather, the occurrence of things and how matters go around. Scientific knowledge use nature in its findings where nature was measured and tested until finally, it was able to give an answer which is believed to benefit human beings and his environment. The scholars then divide science into sub-fields of science, such as computer science, technology, science, applied science, social sciences, political sciences and sports sciences. [2]. Therefore, as the Britain Science Council recently defines it, "Science is the pursuit of knowledge and understanding of the natural and social world following a systematic methodology based on evidence"[3].

\section{SCIENCE, TECHNOLOGY, AND MEDIA: WHERE TO END?}

Today, If we observed the giant energy-based companies and the companies that use technology, they are all so far ahead of others. Some big companies such as Tesla, Google, Apple, Amazon, and Ali Baba have proven now, as a result of technology, that they are in control of businesses throughout the world. The use of technological software has dominated the traditional business industry and this is likely to continue into the future. Uber, for example, is one of the world's largest companies using software tools. They do not have cars, but the company is the world's largest taxi company nowadays. Uber, Trivago and Expedia are also the largest hotel company in the world, despite having no real estate assets. In the same vein, legislation is also expected to face technological competition. This is because society is increasingly using digital technology on legal issues, rather than hiring certain legal persons in the 
handling of legal cases. IBM Watson's on the other hand, can easily provide legal advice quickly via the internet. That means science, through internet technology, will cause a lot of things to be done faster and smoother. Recently, through advancement in science and technology, the self-drive car has begun to be made and operated in most countries of the world while TESLA Company just recently launched its own version of the car brand without a driver. This means that in the near future, car drivers may become increasingly unnecessary. Someone may be able to control his car from a distance and can even control it to pick him up remotely in a particular place at a particular time. In short, the discoveries of science and technology, especially the Internet, have created a situation in which the human being can no longer live comfortably without the internet or as the concept goes "there is no living without the internet". Almost everyone is involved as "Internetphilia". Patelis mention this as follow:

\begin{abstract}
"internetphilia has been announcing the inevitable arrival of a whole new era, one whose features is dramatically different, whose qualities and mechanisms cannot be understood with past methods of analysis. It constantly perpetuates the notion of a clear break with the past. The motor engine of such newness is purely technological; it is a change in essence, a qualitative change[4].
\end{abstract}

In other words, Internetphilia has created a new atmosphere of community in terms of interaction and survival. The social atmosphere of society is now entering a new era where social fabrics differ greatly from the patterns of community in the past. The power or engine that sparked such innovation is eventually the internet and digital technology. The digital world now seems to dominate all aspects of life and social development, politically, socially, economically, culturally, and even religiously. Internet economics have also become a must for all nations and even the advanced society as well. Internet economics involves two things, infrastructure, and content.

TABLE I. INTERNET ECONOMICS

\begin{tabular}{|l|l|}
\hline The content & $\begin{array}{l}\text { Broadcasters, web-casters, online content } \\
\text { providers, website designers, database } \\
\text { providers, advertisers, governments, online } \\
\text { users? }\end{array}$ \\
\hline The infrastructure & $\begin{array}{l}\text { Search engines, navigation tools, ISPs, } \\
\text { hardware, software and server industries } \\
\text { public telecommunication operators }\end{array}$ \\
\hline
\end{tabular}

However, the use of the internet in the community today still leads to social discrimination. The different levels of internet access and usage within communities in the world are unbalanced. Internet access in the developed countries is almost complete, while the internet usage in the underdeveloped and developing countries is still lagging behind. This internet access will make the developed countries continue to develop their businesses and economies, as opposed to developing and underdeveloped countries that will have to continue to struggle economically because of this disadvantage. Thus, large-scale economic and market domination, as well as discrimination in the economic sphere by the developed world towards the underdeveloped and developing countries, will be continuous. In short, economic colonization of the underdeveloped and developing countries by the developed countries will continue without the need to physically colonize them. As a result, social, economic and political unfairness among the world's societies will continue and will hardly be reduced in this age of internetphilia.

But then, we should ask again, where eventually will all this technological system lead us to? Is this technological system able to provide the world community a fair and beneficial life? Or is this technological system only able to benefit a few people or countries? Albeit, does it bring enormous havoc to most of the other population? It is undeniable that world economic domination lies in developed countries where giant companies from these countries are dominating the internet and digital technology.

\section{RELigion, GOVERnMEnt, POWER AND TEChNOLOGY}

I remember when I read [5] that there are at least three factors that make people go into conflict with others throughout history. Among them are religion, state and power. Religion actually involves discussions about life and death, war, morals and conduct, society and way of life. Besides religion are the state and power. These two elements are the most important influence on human beings. The state and the power being the controller of the entire nation/region, often cause and create conflicts and turmoil. So that, the power and state factors made the leaders to continually create new technologies. The aim is to reinforce their economic dominance and social ideology's influences toward the other people and/or nation. In other words, this power through technology can cause them to control the wealth and politics of underdeveloped countries. Social justice and welfare are often sacrificed in the name of modernization. Warfare and conflicts are not caused by the religious extremists, but rather because of regional politics and economic domination by the superpower through their technology and ideology.

There are two superpowers that are still dominant in the political and economic spheres nowadays and they always use their technology for spreading their ideologies all over the world. These superpowers are America and Russia. On its part, America continues to use Capitalism while Russia uses Communism as ideological weapons in addition to technology so as to ensure that their power and influence will continue all over the world. At the same time, they create mass communication gadgets as a major propaganda tool for exporting their cultures and ideologies to all regions and culture of the world.

Through the capabilities of science and technology, these large nations set up multinational companies and reinforce the power of their government through internet technology in order to dominate other nations. The impact 
is huge as they tried to change and shape the modern world according to their own ideology. They managed to dominate the poor countries in a structured and wellplanned way. Their media is an effective tool for spreading their strategies. However, through their effort, it has to be acknowledged that their technologies also give benefits for the betterment of people in the world.

\section{A. What is the purpose of justice and social welfare?}

When people think about social justice, they certainly think about life in the future, that is something that may happen in the future after they study and examine the problem of today. The problem today can be solved if the demands of various parties and people are met and they are treated equally. The concept of social justice thus starts from there. However, the fact that it is difficult for this to be realized makes social justice an important issue in the society. It will be noticed that homeless people, abandoned children, unjust killings and many problems of injustice are everywhere in the world today. Therefore, this shows that the effort to bring social justice to all people must be a continuous and unrelenting one.

What is the meaning of social justice? Social justice can be defined as putting something in its rightful place in the society. Social ownership refers to the needs of every member of the community who are due to be given their rights by other parties. [6] mentions that social justice covers two things, namely, a) providing the required services to members of the community and b) treating members of the public equally. The service may not be up to the quality expected by the people or as they may want it to be, nonetheless, it provides the right opportunity and space for survival. Likewise, all these opportunities needed to be respected and given the value they deserve [7].

People live on a continuous basis. It is likened to a rubber rolling on the road, then pushing the tire to move forward. The clash between the rubber tires of a car and the tarred road is like conflict and competition. This is what life is like. In other words, life is a constant competition aimed at bringing people towards a better life. People who are often exposed to competition will work to make the necessary changes for their goodness in the future. Human society really needs change. The road is tarred, and a suitable rubber tire is used based on the condition of the road, thus, pushing the speed of the car and making it move forward. Here is the analogy of justice in a social system. When the road is good and the same everywhere in a nation, rubber tires are practical and flexible, then all vehicle drivers everywhere in the nation will be able to use the road properly and each vehicle can move fast or at their own pace. This is like justice and equality. If it is sought, practiced and implemented by a wise and just leader, social justice can be exercised smoothly in a nation just as the wheel moves smoothly on a well-tarred road. This is what will spur the development and glory of a nation as well as the human society.

\section{B. The dimensions of Justice and Social welfare from Islamic point of view}

Islam places the value of social change and social justice at the highest level under the concept of maqasid al-shariyyah. There are three main dimensions of this as laid down in Islam, namely dharuriyyah (purpose), goal hajiyah (requirement) and tahsiniyyah (beauty) goals. All three of these goals are aimed at ensuring that social justice and social welfare can be implemented in an Islamic society. If this Maqasid Shariah is observed the way it is laid down in Islam, these three aspects are can help in balancing and strengthening the community's position so that fairness, justice and virtue can reign supreme in the community. The objective of the Shariah is to safeguard religion, life, intellect, heredity and property with the aim of implementing social justice. Thus, if scientific studies bring goodness to humans and provide social justice as a whole, then Islam is the first religion to admit it. It is clear that Islam's view of science and technology is based on the purpose of the science and technology and the aim that they tend to be achieved in the society[8]

Human social life in the past often ignores or does not give priority to social justice. For example, the interest of the people is not given the recognition and priority it deserves by the leaders. As such, religion, property, intellect and honor positions are often neglected in order to achieve the economic interests and political goals of the leaders. Focusing on wasteful mega projects was common without thinking about the welfare and needs of the poor people. Thus, social justice is relegated to the background in favour of economic and political interests. This, therefore, is the cause of the destruction of social justice, even in the Muslim community itself.

As earlier mentioned, social justice in Islam is based on Maqasid al-Shariyyah and intended to control the following six dimensions. First is the dimension of dignity. Social justice seeks to ensure that every individual has a sense of dignity as a human being. Man is glorified naturally without being tied to wealth, rank and lineage. The laws of the nation are created to preserve the dignity of anyone without any discrimination and consideration for wealth, rank and lineage. The second dimension is equality. Social justice seeks to establish equality in law, speech and opportunity in career and economy. This philosophy of equality is to recognize the equality of feeling for everyone in the community. This sharing of feelings will only be realized if each individual can at least be satisfied with legal service, freedom of speech, economic and equal social distribution of wealth and resources.

Brotherhood is the third dimension in ensuring that social justice is implemented. Certainly, this brotherhood involves humanity, spirituality and family affiliation. This humanitarian brotherhood is not given simply on the basis of attachment to religion and family alone. This brotherhood sees all men as belonging to the same humanity, even when they differ in terms of religion and family. Although the brotherhood can also extend to religion and family, both of which bring man together as brothers and sisters, however, it should not be limited to these two areas. This brotherhood is a general theme that is usually ignored in human competition, especially when 
people try to prosecute their own personal interests and benefits. Failure to imbibe the principles of this humanitarian brotherhood also causes some human beings to misbehave towards others. It turns out that in many parts of the world, the issue of tyranny still persists.

The fourth dimension is well being. Social justice or social welfare seeks to bring prosperity to human beings universally. It is a subject of importance to any party's struggle. If we look at an organization or individual, the issue of well being is paramount as seeking prosperity is usually the essence of coming together for all. The well being of humanity is also part of the essence of religion especially Islam.

The fifth dimension is freedom. Freedom is paramount when we talk about social justice. Freedom of speech, movement and association are fundamental rights of every human being. Justice will not be achieved if the imaginations of the mind and physical activities of the body are restricted in a society. Thus, justice will only be achieved when freedom of thought and physical activities are allowed to flourish and grow in the society.

The last dimension is welfare. Welfare has a relationship with virtue and a sense of politeness. The community that prioritizes welfare is a society that supports politeness and kindness to all. This is because welfare is a comprehensive term that encompasses all aspects of human affairs and wellbeing.

From all the above, it is clear that these six dimensions are the ones that point to a society or people who are thought to realize social justice and righteousness. Moving forward from the discussions above, there is another important question which is, whether science is capable of contributing to social justice. In other words, is the result of scientific research able to assure people that they can safeguard their dignity and selfesteem, economic and social equality, strengthen their brotherhood, provide prosperity and good quality of life, encourage independence and promote excellence in the majority of human society?

\section{Science and Social Discrimination}

Science has triggered a phenomenon for the expansion of knowledge so that the boundary of knowledge is now gone. All the networks that contain knowledge can be shared by all people using only one simple gadget. This situation has really changed the whole social and societal system of relationships in many spheres of human life. [3] reports this phenomenon as follows; the family is now getting smaller. The relationship between men and women has changed a lot. Women are more career-oriented, whether they are married or not. Many married couples end up in divorce. Women and men are accepted intelligently and socially as equal. Beliefs on the welfare of a race or nation are diminishing. Social classes still exist, but in the form of wealth, power and media.

These societal changes that are seen in the society are the effect of the explosion of scientific inquiry. However, social justice is still far behind the scientific advancements as many people are still left behind in spite of these changes. Social discrimination in the name of ethnicity and religious belief nevertheless still exists and affect social justice. The media still play a vital role in the spread of hatred about ethnic hostility and religion sentiments. The six dimensions discussed above are still difficult to implement in the community. Power, the state and religious hatred seem to be easily used and manipulated to dominate the ideology of the present era. Injustice and unjust actions in the name of religion, power and regulations still persist among marginalized communities. Through science and technology, the superpower nations are still influencing the minds and ideologies of the developing and underdeveloped countries and this is likely to continue into the near future. This situation may, however, ends if these nations advance their scientific capabilities too especially in information technology.

\section{Science and Technology VS Social Welfare and Justice}

Discussions on the impact of science and technology on social justice and welfare are closely related to the usage of science itself. The moral and ethical motivation that guides humans to create a variety of scientific discoveries is supposed to be considered important - although, it is not being stressed on in our societies right now. Many people are using science for their purpose without ethical and religious guidance or consideration and these scientific researches are always negative with the potential to eventually ruin and destroy their generation and the coming ones. Allah has said in the Quran;

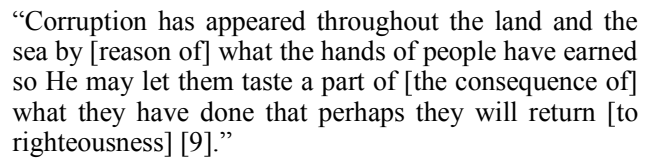

"Corruption has appeared throughout the land and the sea by [reason of] what the hands of people have earned so He may let them taste a part of [the consequence of] what they have done that perhaps they will return [to righteousness] [9]."

Greed and power have brought people to discriminate against others and do anything for a short gain. As a result, the effects of the ecological system in nature, global warming and various disasters are viewed as seriously alarming. Moreover, the invention of nuclear weapons that has brought about a massive destruction seems not to be ending. Hence, how science can bring global justice remains to be seen. Global justice and peace are only in the textbooks and just taught in the educational system. Thus, there is a need for constant and continuing efforts to bring awareness about using science in an ethical manner.

\section{E. Towards Utilizes Science for Social Justice}

Zakat is a pivotal approach in Islamic teachings to counter social problems such as poverty in society. It can be done by sharing a percentage of wealth to relevant recipients as an obligation on the person who affordable it. I have done a study on the management of zakat among the disabled people in a state in Malaysia. The study found that most people with disabilities (OKU) had never received zakat provisions. This situation is distressing because the OKU is the most likely group of people who suffer from social injustice. It is now very easy to get data on OKU. In Malaysia, there is a government department called the Department of Civilization. This department has complete data on OKU and their condition. Scientific research done by this department on OKU data can eventually facilitate the information about the poor and the disabled to be used for the distribution of zakat. 
This is an area where science can help in balancing the social justice in the society.

The science of technologies and the creation of modern equipments can help create social justice, increase dignity and reduce social crimes among the community if properly channel and harness for good purpose. For example, the criminal action by Myanmar among Rohingya Muslims community has caused thousands of people to be killed or driven from their hometown. The operations by Myanmar security forces have driven the Rohingyas off their land, burned down their mosques and committed widespread looting, arson and rape against the Rohingya Muslims. All of these atrocities are known through the help of technology in the media. Unfortunately, though it was called genocide and a massacre of many, the media of the developed nations decided to just ignore them. There is no forceful condemnation of the Rohingyas ethnic cleansing as is usually the case when such thing happens in other climes. Social crimes and injustices continue to happen resulting from the lack of news and proper coverage of events that are considered to be crumbs and not essential in the perspective of the mainstream media, thus, leading to social injustice.

Islam acknowledges that scientific research is good if it brings benefits in general, safeguarding the dignity and bringing virtue to human beings and his society. However, if science and technology provide damage and destruction, it is not allowed. The aim of the Islamic law is to protect the interests of the people. [8] said, If science and technology can be used to facilitate better methods of truth discovery while involving no violation of the Islamic principles, there is no question over their acceptance. An analogy is therefore acceptable that every use of technology that brings and causes crime, social injustice and social exploitation, Islam considers it wrong and it is rejected by Islam. Hence, the epistemology of contemporary science and technology also requires a fair and dignified attitude towards all parties without involving racial, religious and national discrimination. The Islamic views of the merger between science and ethics can make a significant contribution to today's epistemology of science and technology and there is a need for this to be thoroughly examined by today's world community.

\section{CONCLUSION}

Social justice is the responsibility of all parties in achieving the objective of creating an equitable and harmonious society. Religions, such as Islam in particular, have actually shown a clear guide to the communities in realizing how social justice and welfare could be implemented. The key principles of social justice should be sought and uphold in our society. The role of science is to facilitate the above efforts. Now, science has created various facilities for the betterment of human beings in order to develop the world. The creation of the internet and various scientific inventions has brought about tangible changes to the world and those living in it. However, this should not obstruct the fact that there are many adverse effects of science on humanity and the environment. Nonetheless, humans must keep trying to use science in bringing about social goodness and justice.

\section{ACKNOWLEDGEMENT}

We would like to thank to Universitas Muhammadiyah Sidoarjo for supporting this paper publication.

\section{REFERENCE}

[1] J. Lule, Globalization And Media: Global Village Of Babel, Publication Info. Lanham: Rowman \& Littlefield, 2015.

[2] M. Khosrow-Pour, "Encyclopedia Of Information Science And Technology," Hershey Information Science Reference. 2015.

[3] H. M. W, The Impact Of Information On Society. Great Britain: Bowker-Saur, 2001.

[4] P. Korrinna, The Political Economy Of The Internet. Dalam Media Organizations In Society. Oxford: Oxford University Press, 2000.

[5] G. E. Fuller, A World Without Islam. New York: Back Bay Books, 2010.

[6] P. Lynch, Michael J ; Stretesky, Marxism And Social Justice, Dalam Social Justice (Ed. Bruce A. Arrigo). United Kingdom: Wadsworth Publishing Company, 1999.

[7] M. Carnoy, Faded Dreams. Cambridge: University Press, 1994.

[8] M. H. Kamali, "Human Benefits: Science And Technology In Islam," New Straits Times, 2017.

[9] Al-Qur'an 